\title{
TAX TRANSPARENCY - AN ANALYSIS OF THE LUXLEAKS FIRMS
}

\author{
Johannes Manthey \\ University of Würzburg, Würzburg, Germany \\ Dirk Kiesewetter \\ University of Würzburg, Würzburg, Germany
}

\begin{abstract}
This paper finds that the firms involved in the Luxembourg Leaks ('LuxLeaks') scandal are less transparent measured by the engagement in earnings management, analyst coverage, analyst accuracy, accounting standards and auditor choice. The analysis is based on the LuxLeaks sample and compared to a control group of large multinational companies. The panel dataset covers the years from 2001 to 2015 and comprises 19,109 observations. The LuxLeaks firms appear to engage in higher levels of discretionary earnings management measured by the variability of net income to cash flows from operations and the correlation between cash flows from operations and accruals. The LuxLeaks sample shows a lower analyst coverage, lower willingness to switch to IFRS and a lower Big4 auditor rate. The difference in difference design supports these findings regarding earnings management and the analyst coverage. The analysis concludes that the LuxLeaks firms are less transparent and infers a relation between corporate transparency and the engagement in tax avoidance. The paper aims to establish the relationship between tax avoidance and transparency in order to give guidance for future policy. The research highlights the complex causes and effects of tax management and supports a cost benefit analysis of future tax regulation.
\end{abstract}

Keywords: Tax Avoidance, Transparency, Earnings Management

JEL Classification: H20, H25, H26

\section{Introduction}

The Luxembourg Leaks ('LuxLeaks') scandal made public some of the tax strategies used by multinational companies. The firms negotiated advance pricing agreements ('APAs') with the Luxembourg financial authorities which allowed the firms to benefit from favorable tax treatments. Beside competitive reservations, these practices raise ethical questions on the tax behavior of multinational companies. This analysis attempts to analyze the sample of LuxLeaks firms. Corporate transparency is a central issue in the discussion on tax avoidance behavior and tax havens (The Economist 2016). The hypothesis tested is whether there is a relationship between transparency and tax avoidance behaviors.

This paper contributes to the literature by establishing a link between tax and transparency. So far, little is known about the relationship. The analysis uses the LuxLeaks sample because the information was released to the markets unexpectedly. This information release is used as an exogenous event to analyze the relation between tax management strategies and transparency.

The empirical findings of this analysis show that earnings management is a significant explanatory variable of the LuxLeaks sample dummy variable. Both the discretionary earnings management proxy as well as the non-discretionary earnings management proxy are significant. This finding holds for earnings management measured as the variability of net income to cash flow from operations and the correlation between cash flows from operations and accruals. The discretionary earnings management is higher for the LuxLeaks firms. The analyst coverage, the proxy for audit quality and the proxy for quality of financial statements are significant explanatory variables. The coefficients show that the LuxLeaks firms are followed by fewer analysts, were less likely to choose a Big4 auditor or adopt IFRS. In a joint regression model of the transparency variables on the LuxLeaks dummy, the earnings management measures, the 
analyst coverage and the IFRS change date are significant explanatory variables of the LuxLeaks sample. The subsequent difference in differences design analyzes transparency for the firms being part of the LuxLeaks sample and having a ruling applied in the respective year. The regression results indicate that earnings management both measured by the variability of net income to cash flow from operations and the correlation of cash flows from operations and accruals. The analyst coverage is a significant explanatory variable as well. Again, the LuxLeaks firms show higher discretionary earnings management and lower analyst coverage.

The aim of the paper is to demonstrate the relationship between corporate transparency and tax avoidance and give an advice for policy. The insight generated by this paper is supposed to highlight the entangled causes and effects of tax management is supposed to support a cost benefit analysis of future tax regulation. This paper contributes to the existing research by finding evidence that there is a relationship between transparency and the engagement in tax avoidance. Further, this paper gives an understanding which firms tend to use tax management strategies and how they differ compared to other firms. These findings are relevant considering the increased public awareness of tax avoidance and the change in the international tax climate.

\section{Literature}

\subsection{Measures of transparency}

Transparency as defined by Bushman et al. (2004), is characterized by the information availability to firms' outside parties. According to Bushman et al. (2004), financial transparency is based on the intensity and timeliness of financial disclosures as well as coverage by analysts and media. It is captured by the analysts' ability to interpret the information. Governance transparency, is characterized by the intensity of governance disclosures (Bushman et al. 2004). The definition of corporate transparency developed by Bushman et al. (2004) is adapted by various studies in the recent research in the field of accounting (Francis et al. 2009).

The focus on the analyst coverage and analyst forecast accuracy is widely used as a transparency proxy. There is evidence that the analyst forecast accuracy is higher when enforcement standards are high as well based on the argumentation that it reduces the uncertainty about managers' accounting choices (Hope 2003).

Some researches distinguished between government transparency and corporate transparency (Gelos and Wei, 2005). The first is characterized by the timeliness of macroeconomic data and transparency in the macroeconomic policy, the letter is analyzing the financial and information transparency of companies (Gelos and Wei, 2005). The information on the macroeconomic data is based on surveys by the International Monetary Fund and the dispersion of macroeconomic forecasts (Gelos and Wei, 2005). Information of corporations is based on financial disclosures and information availability provided by the World Economic Forum. Subsequently, an index is built out of a score. Gelos and Wei (2005) conclude that the funds tend to allocate their assets in more transparent markets.

There are a variety of proxies of transparency discussed in the literature in the context of taxation and tax avoidance. Balakrishnan et al. (2011) base their proxies on firms' information environments and suggest the analyst forecast error, the analyst forecast dispersion and the accruals quality. The proxies for transparency used by Neuman et al. (2012) are the absolute value of discretionary accruals, the speed of annual report disclosures, analyst forecast dispersion, average bid-ask spread, and average daily trading volume. Neuman et al. (2012) measure uncertainty by the variation in the efficient tax rate.

Öztekin and Flannery (2012) base their analysis of the determinants of capital structure adjustment speeds among others on an asymmetric information index as a proxy for corporate transparency and information sharing. The model by Öztekin and Flannery (2012) for corporate 
transparency uses the quality of accounting standards as an indication, as suggested by LaPorta et al. (1998). The accounting standards are rated by a scale according to general information, income statements, balance sheets, funds flow statement, accounting standards, stock data and special items (LaPorta et al. 1998). The proxies to measures external monitoring by Kim et al. (2011) include the level of analyst coverage, institutional ownership and shareholder rights.

The transparency proxies are delimited from institutional factors and market outcomes (Leuz and Wysocki 2016). The first are investor protection, judicial efficiency and the rule of law, the latter are measures such as the cost of capital, financial development and market capitalization, analyst forecast accuracy, foreign investment, liquidity, ownership structure, etc. According to Leuz and Wysocki (2016), corporate transparency is closely related to other institutional factors and not easily separable. The researchers recommend to separate voluntary and mandatory disclosures in order to examine regulatory differences and firms' practices (Leuz and Wysocki, 2016).

The transparency measures by Lang et al. (2012) are focused on financial transparency. Lang and Maffett (2011) find evidence that lower transaction costs and greater liquidity are associated with greater transparency. The proxies for transparency are the engagement in earnings management, accounting standards, auditor quality, analyst coverage and accurate analyst forecasts (Lang and Maffett 2011). These proxies are covering the measures developed by LaPorta et al. (1998) and extend the methods to more complex methods to capture earnings management and accurate analyst forecast. The focus is changed much more on financial transparency instead of broader comparison of the legal systems of countries. The reliance on analyst forecasts is consistent with the findings of Bilinski et al. (2012) analyzing the determinants of the quality of analyst target price predictions. Bilinski et al. (2012) further argue that the regulatory environment and transparency has a significant association with target price accuracy. The paper extends the argumentation to the relevance of accurate forecasts to the cost of capital. The comparability and transparency of accounting standards are seen as a major determinant of improvements of analyst accuracy (Bilinski et al. 2012). The reliance on the forecasts of analysts follows may also give insights on the cost of equity capital and the residual income models (Chen et al. 2009). Chen et al. (2009) find that strong corporate governance is associated with lower cost of equity capital. The researchers treat transparency as a key element of corporate governance and employ it as an explanatory variable of the equity costs.

The paper of Bleck and Liu (2007) analyze the influence of transparency and financial reporting from an investment perspective, arguing that market transparency enables investors to distinguish good from bad projects. Bleck and Liu (2007) relate the market transparency to asset price crashes and conclude that historic cost accounting transfers volatility across time and inflates asset prices.

The literature showed the relevance of transparency in a variety of ways. Transparency appears to have major positive impact on companies such as advantages in obtaining financing or valuations. The question analyzed is whether firms that are less transparent engage in tax avoidance. Or perhaps firms engaging in tax avoidance increase transparency in other areas to distract from the actions. Similar arguments were raised by Sikka (2010). There is a variety of papers questioning tax management as it may lead to a lack of transparency and agency conflicts. The effects of tax avoidance can potentially lead to managerial opportunism and the diversion of rents, thus being value destructive (Desai and Dharmapala. 2009).

The measures described above show that earnings management proxies and capital market information are among the most widely used ones. The earnings management and analyst based proxies on transparency seem most suitable to accounting focused papers. More exotic measures are used in the economics related papers. With regard to taxation, as analyzed in this paper, the accounting focused measures fit best because of the close link between tax and 
accounting statements. The methods used in this paper are discussed in section 3 in more detail. The measures by Lang et al. (2012) fit well to a taxation focused paper due to their emphasis on accounting standards and data availability also for non US companies.

\subsection{The relationship between tax avoidance and transparency}

The negative effect of the engagement in tax avoidance on corporate transparency is acknowledged by Armstrong et al. (2015) in their analysis on corporate governance and incentives. Kim et al. (2011) analyzing stock price crash risk, find that information transparency is negatively related to crash risk arguing that lower transparency may allow managers to hide information. The argumentation of Kim et al. (2011) is based on the agency framework and assumes that tax avoidance creates agency costs and information asymmetries. The lower transparency leads to an accumulation of negative information that causes stocks to plumb once released to the market (Kim et al. 2011). Firms with higher tax sheltering, lower long-run effective tax rates and larger book-tax differences show a higher risk of stock price crashes (Kim et al. 2011). Strengths in external monitoring however mitigate the future cash risk associated with tax avoidance. The study by Guedhami and Pittman (2006) finds that agency costs can be mitigated by accounting transparency. The study investigates privatization offers with regard to disclosure standards and auditor-related information in order to explain ownership concentration across countries (Guedhami and Pittman, 2006). Transparency, used as an independent variable, captures a disclosure index for information available to minority investors, Big4 auditors, the possibility to sue the auditor and the burden of proof in criminal prosecutions of auditors for misleading financial information (Guedhami and Pittman, 2006). In addition, institutional and legal proxies for the legal origin, the level of rights of minority shareholders, the efficiency of the judicial system, the enforcement of the legal rules, the competition environment based on survey data, circulation of newspapers and the extent of tax enforcement are employed in the analysis. The paper by Balakrishnan et al. (2011) finds evidence that aggressive tax planning decreases corporate transparency. The researchers find that firms engaging in tax avoidance show higher analyst forecast errors and analyst forecast dispersion, higher information asymmetry and lower accruals quality (Balakrishnan et al. 2011). Balakrishnan et al. (2011) further conclude that transparency problems are lower for firms engaged in tax avoidance that provide additional disclosures. The discussion of the relation between tax avoidance and transparency goes in a similar direction as the agency cost argument developed by Desai and Dharmapala (2006). Following Desai and Dharmapala (2006), the engagement in tax avoidance strategies causes agency problems which allow managers the diversion of rents. A study by Neuman et al. (2012) analyzed whether sustainability of firms' tax strategies associated with corporate transparency. Neuman et al. (2012) found that sustainable tax strategies are related to more transparent information environments. Further, firms with superior sustainable tax strategies show a higher financial performance (Neuman et al. 2012). Conclusively, Neuman et al. (2012) argue that transparency significantly affects the cost of capital and, thus, the engagement in tax management can be costly.

In the previous literature, few papers analyzed the relationship between tax and transparency. There are studies which found evidence for a negative relationship between tax avoidance and transparency. However, in the US most papers analyze sample. The terms 'tax' and 'transparency' are used together in a lot of discussions in the tax law and OECD literatures. This paper attempts to establish the relationship between tax and transparency for European companies. Further, the analysis is supposed to clarify the drivers of tax management as well as characteristics that may foster the engagement in aggressive tax planning. 


\section{Data and research design}

\subsection{Sample}

The sample of this analysis comprises 345 firms named in the LuxLeaks database (ICIJ 2014). The sample is subject to limitations on data availability. As non-missing values are required, 168 firms remain and built the treatment group 'Sample'. A control group is built, consisting of multinational firms having the headquarters in the counties identified in the LuxLeaks papers (Huesecken and Overesch 2015). The data for the transparency measures is taken from the Thomson Reuters Datastream database. The rulings of the LuxLeaks firms cover the period from 2003 to 2011. The discovery of the rulings did not make them invalid or illegal and it is assumed that the firms' tax avoidance behavior did not change because of that. That panel data covers the years from 2001 to 2015 assuming that the rulings were negotiated some time in advance and stay in place longer than just one year. The control group comprises 1105 firms. It is assumed that the APAs are negotiated by large public listed multinational companies. Considering the costs of setting up the rulings, firms need to have a certain size and revenue to make the effort worth it. The negotiation of the rulings most likely was pretty costly and the large majority of rulings were filed by large multinationals. The other rulings, mostly by partnerships, foundations or individuals, might have been filed for different reasons than transparency, e.g. hiding the identity of individuals. Therefore, the control group is made up of the S\&P 500 and the Stoxx Europe 600 to select firms similar to those in the LuxLeaks sample. The panel dataset comprises 19,109 observations. Missing data limits the regression analysis to fewer observations as non-missing values are required for all variables.

\subsection{Methodology}

The most widely discussed measures of transparency are the analyst related proxies and financial statement quality proxies. The choice of measures is narrowed down to earnings management, audit quality, accounting standards, analyst coverage and analyst forecast accuracy as outlined by Lang et al. (2012), Lang and Lundholm (1996) and Lang and Maffett (2011).

Earnings management is measured by the variability of net income relative to cash flows from operations and correlation between accruals and cash flows from operations (Lang and Maffett 2011).

$$
\frac{\sigma(\text { Net Income })}{\sigma(\text { CF Operations })} \text { and } \operatorname{Corr}(\triangle A c c u r a l s, \Delta C F \text { Operations })
$$

The measures assume firms build accruals to manage earnings (Lang et al. 2012). It follows, that the volatility of earnings relative to the volatility of cash flows is lower (Lang et al. 2012). Similarly, accruals and cash flows are negatively related as accruals are assumed to be used in bad times to offset cash flows (Lang et al. 2012). The weakness of this smoothing measure arises from the difficulty of detangling smoothness of the fundamental earnings process, accounting rules and intentional earnings manipulation (Dechow et al. 2010). The accruals are supposed to give a leeway for decisions to overcome a mismatch of cash in-/outflows and ultimately archive a representation of the fundamental performance (Dechow et al. 2010). However, the smoothness resulting from accruals can allow to hide or delay the measurement of changes in fundamental performance (Dechow et al. 2010). It follows to question whether choice results in greater earnings management and in which way earnings management affects reporting quality (Dechow et al. 2010). The subsequent analysis focuses on the latter and assumes increased earnings management is associated with lower reporting quality due to a lack of transparency.

The volatility of earnings relative to the volatility of cash flows is measured by the standard deviation of the net income scaled by total assets over the standard deviation of the cash flow 
from operations. The cash flow from operations is defined as the net income before extraordinary items minus accruals. The accruals are calculated by the change in current assets less the change in current liabilities less the change in cash plus the change in current debt less the depreciation and amortization. The first measure takes the correlation between the cash flow from operations scaled by total assets and the total accruals scaled by total assets (Lang and Maffett, 2011). The second measure, divides the standard deviation of the earnings by the standard deviation of cash flow from operations (Lang and Maffett, 2011). Both earnings management measures are multiplied by minus one such that a higher value implies higher earnings management. The procedure by Lang and Maffett (2011) suggests a regression of the determinants of discretionary earnings smoothness on each of the two measures of earnings management (Lang and Maffett, 2011). The determinants used in this analysis are the log of total assets, leverage (total debt to common equity) capturing the financing choice, BV to MV of equity reflecting growth expectations, volatility of sales capturing the operating performance, frequency of accounting losses capturing accrual policies, sales growth capturing growth opportunities, operating leverage (PPE scaled by total assets) capturing capital intensiveness, cash flows from operations (CFO scaled by total assets) capturing the profitability and year / country / industry fixed effects (Lang and Maffett, 2011). Subsequently, the residuals are used to form a measure of discretionary earnings smoothness, which are then used as a predictor of greater earnings management (Lang and Maffett, 2011).

$$
\begin{gathered}
\operatorname{Corr}(\Delta \text { Accurals, } \triangle C F \text { Operations })=\frac{C F \text { Operation }}{\text { Total assets }}+\frac{\text { Accruals }}{\text { Total assets }}+\frac{M V}{B V}+\frac{D}{E}+\text { FreqLoss }+ \text { STDSales }+ \text { Oplev }+ \text { Sales Growth } \\
\frac{\sigma(\text { Net Income })}{\sigma(\text { CF Operations })}=\frac{C F \text { Operation }}{\text { Total assets }}+\frac{\text { Accruals }}{\text { Total assets }}+\frac{M V}{B V}+\frac{D}{E}+\text { FreqLoss }+ \text { STDSales }+ \text { Oplev }+ \text { Sales Growth }
\end{gathered}
$$

The procedure separates fundamental earnings management from discretionary earnings management (Lang et al. 2012). Distinguishing between artificial smoothness and smoothness of fundamental performance helps to understand the consequence of smoothness resulting from choice, e.g. due to opportunistic behavior (Dechow et al. 2010). This separation attempts to account for managerial incentives and institutional constraints (Lang et al. 2012). The procedure of this paper follows the construction of the discretionary earnings management measure. Different from the existing research, the discretionary earnings management is analyzed on a company basis. Further, the number of analysts, a dummy for a Big4 auditor and a dummy for a switch to IFRS are included in the regression. Variables such as an anti-selfdealing proxy as suggested by Djankov et al. (2008) are not included due to a lack of data availability for the non-US companies. The analysis deviated from the framework developed by Lang et al. (2012) by not including a proxy for the alignment of tax and financial reporting as suggested by Ashbaugh-Skaufe and Lafond (2004). This analysis belongs to the 'consequences' papers because earnings management and the following measures of transparency are used as independent variables and the aim is to clarify the impact of transparency on tax avoidance behavior (Dechow et al. 2010).

The audit quality is measured by analyzing the auditor. An audit by a Big4 company is considered to be of higher quality (Lang and Maffett, 2011). The large professional service companies are assumed to have greater experience and enhance compliance with accounting standards (Hope 2003). A dummy variable is created and assigned the value 1 if the auditor was a Big4 company, otherwise the value 0 is given.

The reporting under the IFRS is used as a proxy for accounting standards. The IFRS using companies are distinguished in voluntary and mandatory adopters to separate assuming the latter show less capital-market effects as suggested by Daske et al. (2008) and Leuz and Wysocki (2016). The IFRS change date is accessible and transferred in a dummy variable taking the value 1 if the date is published and 0 if it was not published. 
The number of analysts forecasting the firms' earnings is used as a proxy for the analyst coverage (Lang and Maffett, 2011). A higher number of financial analysts is assumed to represent higher information processing and to some extend monitoring of the firms. The focus on analysts allows a focus solely on earnings, while the market prices reflect other information as well (Dechow et al. 2010). However, analysts may be biased or anticipate accruals management, etc. (Dechow et al. 2010).

Lastly, the accuracy of analyst forecasts is employed as a transparency proxy. The procedure follows Lang and Lundholm (1996) and Lang and Maffett (2011). The proxy is based on the residuals of the regression of the accuracy measure on the forecast error and the unexpected earnings. The accuracy measure is the absolute forecast error multiplied by minus one over the stock price by the end of the fiscal year $\mathrm{t}-1$. The forecast error is the analyst mean annual earnings forecast minus the actual earnings. The forecast error as an absolute value is used as the dependent variable. The independent variables are the following: The first independent variable is the analyst forecast error over the stock price by the end of the fiscal year t-1, again, the forecast error is the analyst mean annual earnings forecast minus the actual earnings. The second independent variable is the unexpected earnings over the stock price by the end of the fiscal year $\mathrm{t}-1$, here, the unexpected earnings are the earnings per share year $t$ minus the earnings per share from the year $\mathrm{t}-1$. The residuals are subsequently used as a proxy for the accuracy of the analyst forecast.

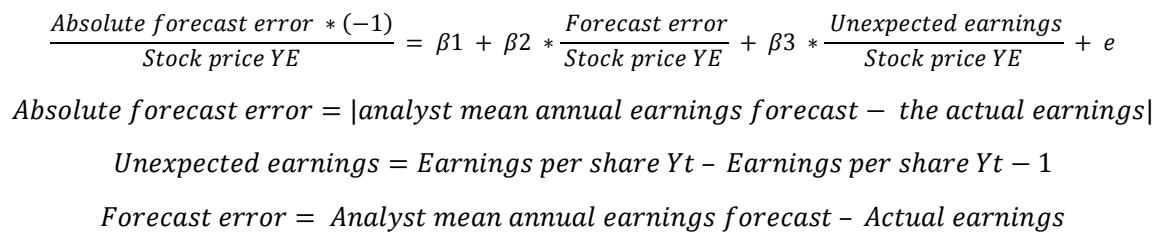

In the next step, the LuxLeaks dummy is regressed on the proxies of earnings management. The dummy indicates whether the firm is among the ruling firms in the sample. The test procedure applies a fixed effects regression model.

The two dummy variables are tested in separate regressions. First, the variable 'Sample' indicates whether a firm is part of the LuxLeaks sample. This assumes that firms being in the LuxLeaks sample are in general less transparent. Second, the variable 'SampleRuling' indicates whether a firm is in the LuxLeaks firms and applied a ruling in the respective year. The difference in differences is capturing the year in which the ruling was negotiated. This test procedure attempts to relax the assumption of a general lack of transparency of the sample firms independent of the ruling period. It is assumed that the LuxLeaks firms were companies like any other large listed corporation. These are taken as the control group. This analysis supposes that the treatment group chose to negotiate a tax ruling in Luxembourg. The choice element is crucial as there is in most cases no other economic reason behind the rulings beside tax avoidance. The difference in differences design assumes the firms would have moved the same way otherwise if there was not the publication of the LuxLeaks scandal. This is a hard assumption because it seems likely, that there are other tax avoiders in the control group which were using the same rulings and may still do so or could have abandoned the ruling strategies beside not being directly affected by the Luxembourg scandal. Furthermore, the rulings date back in time quite long and the international tax climate has changed. The public awareness increased and the countries closed loopholes in their tax legislations. The underlying trends of tax avoidance and the determinants of engaging in tax management may be different to the time the rulings were negotiated. However, for this analysis it is assumed that the treatment group and the untreated control group moved in the same way.

Ruling Firm $=\beta 1+\beta 2$ Earnings management $+\beta 3$ Audit Quality $+\beta 4$ Accounting Standards $+\beta 5$ Analyst Coverage $+\beta 6$ Analyst Forecast Error $+\sum \beta 7$ Controls $+\sum \beta 8$ Fixed Effects Year / Country / Industry $+\mathrm{e}$ 
The regression model includes control variables for size, book-to-market value, cash and cash equivalents, sales, sales general and admin expense, debt to equity and the return on equity as well as fixed effects for the year, country and industry.

\section{Empirical results}

The empirical results section first analyses the descriptive statistics and the correlation matrix. Subsequently, the transparency measures are regressed on the LuxLeaks dummy variables. Then, the difference in differences design examines the relation of transparency and tax aggressiveness for firms both having a ruling applied and being among the LuxLeaks firms. An overview over the variables is displayed in Table 1. The findings are presented in the following.

The descriptive statistics (Table 2) give an overview over the variables of the panel data set. The data covers the years from 2001 to 2015 by firm level observations at year end. The correlation matrix (Table 3) reveals the first pairwise relationship of the variables.

The regressions of the transparency measures on the dummy variable 'Sample', indicating that a firm is part of the LuxLeaks sample, are presented in the following. The first regression (Table 4 , Column 1) shows that the variability of net income in relation to cash flows from operations is a highly significant explanatory variable. Similarly, the residuals of the earnings management proxy are highly significant. The first term indicates the fundamental earnings management. Second, the residuals show the discretionary earnings management. Similarly, the regression of the correlation between cash flow from operations and accruals (Table 4, Column 2) gives similar results. The correlation between cash flow and accruals as well as the residuals are highly significant explanatory variables. The negative coefficient of the correlation between cash flows from operations and accruals indicates that accruals may be used to offset cash flows. The sign of the coefficients is interpreted in such a way that the LuxLeaks firms show higher earnings management. The regression of the forecast accuracy on the dummy variable (Table 4, Column 3) is not significant. The analyst coverage displayed in the regression (Table 4, Column 4) is significant. The audit quality dummy tested in the regression (Table 4, Column 5) is significant, as well as the IFRS change date (Table 4, Column 6). The negative coefficients indicate that that lower analyst coverage, lower audit quality and no change to IFRS are associated with the LuxLeaks sample.

The transparency variables are tested in a joined model (Table 5) to see the overall impact. The transparency measures are regressed on the dummy variable 'Sample' (Table 5, Column 1) indicating whether a firm was among the LuxLeaks firms. The regression on the dummy variables 'Sample Ruling' (Table 5, Column 2) captures firms that were both part of the LuxLeaks sample and had a ruling in the respective year. The regression results for the variables 'Sample' (Table 5, Column 1) show that the earnings management measures are highly significant, both the measures as well as the residuals indicating the discretionary earnings management. The variability of net income to cash flow and the residual measures are significant. Same holds for the correlation between cash flow and accruals and the respective residuals measures. The positive coefficients of discretionary earnings management indicate higher smoothing for the LuxLeaks sample. The analyst coverage and the IFRS change date have significant explanatory power as well. The coefficients indicate that LuxLeaks firms have a lower analyst coverage and IFRS change date willingness.

The regression of the transparency measures on the dummy variable 'SampleRuling' (Table 5, Column 2) indicates that the correlation between cash flow and accruals as well as the residuals from the discretionary regression model are highly significant. Again, the discretionary earnings management is higher for LuxLeaks companies. Further, the analyst coverage is a significant explanatory variable and lower for LuxLeaks firms. 
The individual regressions of the transparency variables on the sample ruling is part of the difference in differences design. The dummy variable 'SampleRuling' is indicating whether a firm is both part of the LuxLeaks sample and had a ruling applied in the respective year. The regression output shows that the earnings management variables have significant explanatory power. The variability of net income to cash flows from operations and the residuals from the regression of the measure on the fundamentals of earnings management are significant. The correlation between cash flow and accruals, same as the residuals from regressing the measure on the fundamentals of earnings management are highly significant. It appears that earnings management has significant explanatory power and the discretionary earnings management is higher for LuxLeaks firms. The analyst coverage is significant and shows a negative coefficient, so the LuxLeaks firms are followed by fewer analysts.

The results above do not yet make claims about the causation of the relationship. The analysis cannot proof the direction of the relation, whether the LuxLeaks firms are among the tax avoiders because they are less transparent and tend to engage in earnings management, or alternatively, a lack of transparency leads to companies becoming tax avoiders. Since no explanation is implausible, none can be ruled out.

Leuz et al. (2003) find that the relationship between earnings management and corporate governance is likely to be endogenous. The level of discourse is not seen as an exogenous factor in explaining financing and ownership (Leuz et al. 2003). Similarly, earnings management and transparency may act as complements and joint outcomes. The relation could be similar between tax and transparency. This could be the case because reverse causality is possible. On the one hand, it seems reasonable that firms that engage in tax avoidance are less transparent because of the tax avoidance behavior itself. The complex legal structures or adjustments of the companies' operations to fit through tax loopholes may be the result of a lack of transparency. On the other hand, less transparent firm could engage in tax avoidance because the lack of transparency leads to a different risk attitude or agency conflicts. At this point it remains questionable whether tax avoidance generates value. Both stories above appear plausible. Nevertheless, a causation remains unclear because we cannot assume an exogenous source of variation and thus the analysis suffers from an endogeneity bias. The two models are equally consistent with the data and the assumption that either tax or transparency can individually be varied, is violated with complementarity.

Endogeneity could be addressed by restrictions on data, the elimination of alternative explanations, randomized or natural experiments or the use of an instrument as a source of exogenous variation. The restrictions on the data are attempted by introducing fixed effects models on the year, industry and firm level. The alternative explanations discussed above are acknowledged as a main cause of an endogenous bias. The LuxLeaks sample is selected as an event that has some exogenous elements in the relation between tax and transparency, assuming it was a random discovery introduced from outside to the 'tax avoidance world'.

A further problem of the sample is the possible self-section. The choice of the sample of the LuxLeaks firms itself is selective as in many cases the choice of going to Luxembourg is motivated by tax reasons only. Possibly, transparency reasons play a similar role as well. In this setting, the difference between the firms is observable from the published list, but the assignment to the treatment group (the LuxLeaks sample) is most likely not random as tax avoidance behavior and the location decision involves a choice. Fixed effects are introduced to control for some of the unobserved heterogeneity. The actual tax behavior is unobserved and merely measured by the binary variable based on whether the firm is in the sample of the LuxLeaks firms or not. The fact that a company negotiated a ruling does not necessarily mean that the tax avoidance behavior was successful. The rulings could be taken up in foreign tax audits or remained unapplied for underlying economic reasons such as a lack of taxable profits. 
Possibly, beside the endogeneity, the results may suffer from omitted correlated variables and concurrent events (Ball et al. 2015).

\section{Conclusion}

This paper analyzed the transparency of the firms that were part of the LuxLeaks scandal. Corporate transparency is a recurring policy issue. This study contributes to existing research by establishing evidence for the relationship between tax avoidance and transparency. The aim of the paper is to give guidance for future policy decisions. In conclusion, the main finding is that the LuxLeaks firms are less transparent compared to the control group. Thus it is inferred, that there is a relationship between a lack of transparency and tax avoidance behavior.

The analysis above showed that earnings management appears to be related to transparency as well as aggressive tax behavior. Both the discretionary and the non-discretionary variables are significant in explaining tax avoidance. The results indicate that this holds both measured by the variability of net income to cash flows from operations and the correlation between cash flows from operations and accruals. The coefficients indicate that earnings management is higher for the LuxLeaks firms. Similarly, the analyst coverage, audit quality and the financial statement quality play a significant role. For the latter three, the transparency measures are lower for the LuxLeaks sample. These findings hold for the regression on the dummy variable indicating the LuxLeaks firms as well as the difference in differences design focusing on the intersection of sample firms having a ruling applied in the respective year. The study could imply that increased transparency requirements would reduce tax avoidance behavior. The main question that arises from this idea is whether the benefits of disclosure regulation outweigh the costs. Most important, how to quantify the costs. Further, the disclosure and transparency requirements could be seen as a benign form of regulation as Leuz and Wysocki (2016) point out. This means requiring disclosure about certain activity and regulating by attention and awareness. The economic consequences of disclosure regulation with regard to taxation are not yet apparent. Possibly, the regulation may not work. The benefits of disclosure indicated by this study does not necessarily justify mandatory disclosure regulation. If additional disclosures were beneficial for the firms, they would increase their disclosure without a regulatory act. One could argue against this, that disclosure may enhance competition, bring positive externalities to the economy and overcome deadweight costs from the economy.

\section{References}

Armstrong, C. S. et al. (2015). Corporate governance, incentives, and tax avoidance. Journal of Accounting and Economics, 60 (1), pp.1-17.

Available at: http://linkinghub.elsevier.com/retrieve/pii/S0165410115000178.

Ashbaugh-Skaufe, H., Lafond, R. (2004). Reporting Incentives and the Quality of Non-U.S. Firms' Working Capital Accruals. Working paper. University of Wisconsin.

Balakrishnan, K., Blouin, J., Guay, W. (2011). Does Tax Aggressiveness Reduce Corporate Transparency? Social Science Research Network Working Paper Series.

Available at: http://ssrn.com/abstract=1792783.

Ball, R. A. Y., Li, X. I., Shivakumar, L. (2015). Contractibility and Transparency of Financial Statement Information Prepared Under IFRS: Evidence from Debt Contracts Around IFRS Adoption. Journal of Accounting Research, 53 (5), pp. 915-963.

Available at: http:https://dx.doi.org/10.1111/1475-679X.12095.

Bilinski, P., Lyssimachou, D., Walker, M. (2012). Target Price Accuracy: International Evidence. The Accounting Review, 88 (3), pp. 825-851.

Available at: http://dx.doi.org/10.2308/accr-50378. 
Bleck, A., Liu, X., 2007. Market Transparency and the Accounting Regime. Journal of Accounting Research, 45 (2), pp. 229-256.

Available at: http://dx.doi.org/10.1111/j.1475-679X.2007.00231.x.

Bushman, R. M., Piotroski, J. D., Smith, A. J. (2004). What Determines Corporate Transparency? Journal of Accounting Research, 42 (2), pp. 207-252.

Available at: http://dx.doi.org/10.1111/j.1475-679X.2004.00136.x.

Chen, K. C. W., Chen, Z., Wei, K. C. J. (2009). Legal protection of investors, corporate governance, and the cost of equity capital. Journal of Corporate Finance, 15 (3), pp. 273-289. Available at: http://www.sciencedirect.com/science/article/pii/S0929119909000029.

Daske, H. et al. (2008). Mandatory IFRS Reporting around the World: Early Evidence on the Economic Consequences. Journal of Accounting Research, 46 (5), pp. 1085-1142. Available at: http://www.jstor.org/stable/40058120.

Dechow, P., Ge, W., Schrand, C. (2010). Understanding earnings quality: A review of the proxies, their determinants and their consequences. Journal of Accounting and Economics, 50 (2-3), pp. 344-401.

Available at: http://www.sciencedirect.com/science/article/pii/S0165410110000339.

Desai, M. A., Dharmapala, D. (2009). Corporate Tax Avoidance and Firm Value. The Review of Economics and Statistics, 91 (3), pp. 537-546.

Available at: http://econpapers.repec.org/RePEc:tpr:restat:v:91:y:2009:i:3:p:537-546.

Desai, M. A., Dharmapala, D. (2006). Corporate tax avoidance and high-powered incentives. Journal of Financial Economics, 79 (1), pp. 145-179.

Available at: http://www.sciencedirect.com/science/article/pii/S0304405X05001364.

Djankov, S. et al., 2008. The law and economics of self-dealing. Journal of Financial Economics, 88 (3), pp.430-465.

Available at: http://www.sciencedirect.com/science/article/pii/S0304405X08000160.

Francis, J. R. et al. (2009). Does Corporate Transparency Contribute to Efficient Resource Allocation? Journal of Accounting Research, 47 (4), pp. 943-989.

Available at: http://dx.doi.org/10.1111/j.1475-679X.2009.00340.x.

Gelos, R. G., Wei, S.-J. (2005). Transparency and International Portfolio Holdings. The Journal of Finance, 60 (6), pp. 2987-3020.

Available at: http://dx.doi.org/10.1111/j.1540-6261.2005.00823.x.

Guedhami, O., Pittman, J. A. (2006). Ownership Concentration in Privatized Firms: The Role of Disclosure Standards, Auditor Choice, and Auditing Infrastructure. Journal of Accounting Research, 44(5), pp. 889-929.

Available at: http:https://dx.doi.org/10.1111/j.1475-679X.2006.00219.x.

Hope, O. (2003). Disclosure Practices, Enforcement of Accounting Standards, and Analysts' Forecast Accuracy: An International Study. Journal of Accounting Research, 41 (2), pp. 235272.

Available at: http:https://dx.doi.org/10.1111/1475-679X.00102.

Huesecken, B., Overesch, M. (2015). Tax Avoidance through Advance Tax Rulings - Evidence from the LuxLeaks Firms. Social Science Research Network Working Paper Series.

Available at: http://ssrn.com/abstract=2664631.

ICIJ, I.C. of I. J. (2014). Explore the Documents: Luxembourg Leaks Database.

Available at: https://www.icij.org/project/luxembourg-leaks/explore-documents-luxembourgleaks-database. 
Kim, J.-B., Li, Y., Zhang, L. (2011). Corporate tax avoidance and stock price crash risk: Firmlevel analysis. Journal of Financial Economics, 100 (3), pp. 639-662.

Available at: http://www.sciencedirect.com/science/article/pii/S0304405X1100033X.

Lang, M., Lins, K. V, Maffett, M. (2012). Transparency, Liquidity, and Valuation: International Evidence on When Transparency Matters Most. Journal of Accounting Research, 50 (3), pp. 729-774.

Available at: http://dx.doi.org/10.1111/j.1475-679X.2012.00442.x.

Lang, M., Lundholm, R. J. (1996). Corporate Disclosure Policy and Analyst Behavior. The Accounting Review, 71 (4), pp. 467-492.

Available at: http://www.jstor.org/stable/248567.

Lang, M., Maffett, M. (2011). Transparency and liquidity uncertainty in crisis periods. Journal of Accounting and Economics, 52 (2-3), pp.101-125.

Available at: http://www.sciencedirect.com/science/article/pii/S0165410111000553.

LaPorta, R. et al. (1998). Law and Finance. Journal of Political Economy, 106 (6), pp. 1113 1155.

Leuz, C., Nanda, D., Wysocki, P. D. (2003). Earnings management and investor protection: an international comparison. Journal of Financial Economics, 69 (3), pp. 505-527.

Available at: http://www.sciencedirect.com/science/article/pii/S0304405X03001211.

Leuz, C., Wysocki, P. D. (2016). The Economics of Disclosure and Financial Reporting Regulation: Evidence and Suggestions for Future Research. Journal of Accounting Research, 54 (2), pp. 525-622.

Available at: http://dx.doi.org/10.1111/1475-679X.12115.

Neuman, S., Omer, T., Shelley, M. (2012). Corporate Transparency, Sustainable Tax Strategies, and Uncertain Tax Activities. Social Science Research Network Working Paper Series. Available at: http://ssrn.com/abstract=2184892.

Öztekin, Ö., Flannery, M. J., (2012). Institutional determinants of capital structure adjustment speeds. Journal of Financial Economics, 103 (1), pp. 88-112.

Available at: http://www.sciencedirect.com/science/article/pii/S0304405X11001978.

Sikka, P. (2010). Smoke and mirrors: Corporate social responsibility and tax avoidance. Accounting Forum, 34 (3-4), pp.153-168.

The Economist, 2016. The biggest loophole of all. The Economist Newspaper Limited. 
Table 1. Description of variables

Variable

Sample

SampleRuling

VarNetInco

Res VarNetI

CorrCFoAcc

ResCorrCF

ResRawAcc

AnalCov

AuditD

IFRSChaD

MV

P/B

SALES

CASH

PPE

SG\&A

$\mathrm{D} / \mathrm{E}$

ROE

\section{Description}

Dummy variables ruling firm of the LuxLeaks sample ( 1 for being in the sample, 0 otherwise)

Dummy variables ruling firm multiplied by ruling period (1 for ruling applied in the year, 0 otherwise)

Variability of net income $=$ standard deviation of net income over the standard deviation of cash flows from operations; both scaled by total assets

Residual values of the regression of the variability of net income on the cash flow from operations, accruals over total assets, total assets, market to book value, debt to equity, frequency of loss dummy, standard deviation of sales, sales growth and operating leverage (PPE over total assets)

Correlation of cash flow of operations and accruals calculated by grouping on firm level

Residual values of the regression of the correlation of cash flow of operations and accruals on the cash flow from operations, accruals over total assets, total assets, market to book value, debt to equity, frequency of loss dummy, standard deviation of sales, sales growth and operating leverage (PPE over total assets)

Residuals of the regression of the absolute forecast error (analyst mean annual earnings forecast minus the actual earnings) on the unexpected earnings (earnings per share time $t$ minus earnings per shares time $t-1$ ) and the signed analyst forecast error (analyst mean annual earnings forecast minus the actual earnings)

Analyst coverage as the number of analyst following a company

Big4 Auditor dummy

IFRS Change date dummy

Ln of the market capitalization

Price to book value

Revenues

Cash and cash equivalents

Property, plant and equipment

Sales, general and admin expense

Leverage ratio as total debt to common equity

Return on equity 
Table 2. Descriptive statistics

$\begin{array}{llllll}\text { Variable } & \text { Obs } & \text { Mean } & \text { Std. Dev. } & \text { Min } & \text { Max } \\ \text { VarNetInco } & 17,684 & -.0003042 & .0089082 & -.3006971 & -3.36 \mathrm{e}-11 \\ \text { ResVarNetI } & 7,401 & -5.23 \mathrm{e}-14 & .0006253 & -.0516066 & .0016549 \\ \text { CorrCFoAcc } & 10,605 & -.0186235 & .3718267 & -1 & 1 \\ \text { ResCorrCF } & 7,397 & -1.14 \mathrm{e}-10 & .3644386 & -1.131283 & 1.164904 \\ \text { ResRawAcc } & 14,863 & -4.35 \mathrm{e}-11 & .2600421 & -13.13679 & .4246294 \\ \text { AnalCov } & 15,345 & 15.93653 & 8.40921 & 1 & 54 \\ \text { AuditD } & 17,970 & .9381747 & .2408446 & 0 & 1 \\ \text { IFRSChaD } & 17,970 & .4490818 & .4974144 & 0 & 1 \\ \text { MV } & 15,859 & 8.903655 & 1.638371 & -5.878136 & 15.90949 \\ \text { P/B } & 15,641 & -60.43376 & 3462.839 & -264706 & 3109.76 \\ \text { SALES } & 16,516 & 15.4882 & 1.761418 & 2.397895 & 22.52778 \\ \text { CASH } & 13,413 & 12.74319 & 2.084307 & 0 & 20.89827 \\ \text { PPE } & 16,229 & 14.08169 & 2.136223 & 1.098612 & 23.12151 \\ \text { SG\&A } & 13,289 & 13.72547 & 1.856754 & 0 & 20.69176 \\ \text { D/E } & 16,502 & 124.1798 & 1190.744 & -77921.74 & 45539.02 \\ \text { ROE } & 15,916 & 18.94349 & 166.9975 & -4695.2 & 12109.6\end{array}$


Table 3: Correlation matrix

\begin{tabular}{|c|c|c|c|c|c|c|c|c|c|c|c|c|c|c|c|c|c|c|}
\hline & $\begin{array}{l}\text { Sample } \\
\text { Ruling }\end{array}$ & $\begin{array}{l}\text { Sam } \\
\text { ple }\end{array}$ & $\begin{array}{l}\text { VarNet } \\
\text { Inco }\end{array}$ & $\begin{array}{l}\text { ResVa } \\
\text { rNetI }\end{array}$ & $\begin{array}{l}\text { Corr } \\
\text { CFo } \\
\text { Acc }\end{array}$ & $\begin{array}{l}\text { ResCo } \\
\text { rrCF }\end{array}$ & $\begin{array}{l}\text { ResRa } \\
\text { wAcc }\end{array}$ & $\begin{array}{l}\text { Anal } \\
\text { Cov }\end{array}$ & $\begin{array}{l}\text { Audi } \\
\text { tD }\end{array}$ & $\begin{array}{l}\text { IFRS } \\
\text { ChaD }\end{array}$ & MV & $\mathbf{P} / \mathbf{B}$ & Sales & CASH & PPE & SG\&A & $\mathbf{D} / \mathbf{E}$ & ROE \\
\hline SampleRuling & 1 & & & & & & & & & & & & & & & & & \\
\hline Sample & 0.23 & 1 & & & & & & & & & & & & & & & & \\
\hline VarNetInco & 0.01 & 0.00 & 1 & & & & & & & & & & & & & & & \\
\hline ResVarNetI & 0.02 & 0.11 & 0.24 & 1 & & & & & & & & & & & & & & \\
\hline CorrCFoAcc & -0.01 & -0.02 & 0.07 & 0.00 & 1 & & & & & & & & & & & & & \\
\hline ResCorrCF & 0.00 & 0.01 & 0.07 & 0.03 & 0.99 & 1 & & & & & & & & & & & & \\
\hline ResRawAcc & 0.00 & 0.01 & 0.04 & 0.03 & -0.03 & -0.03 & 1 & & & & & & & & & & & \\
\hline AnalCov & 0.00 & -0.06 & 0.17 & -0.26 & 0.02 & 0.01 & 0.05 & 1 & & & & & & & & & & \\
\hline AuditD & 0.01 & 0.01 & 0.09 & -0.02 & -0.06 & -0.06 & 0.00 & 0.04 & 1 & & & & & & & & & \\
\hline IFRSChaD & -0.02 & -0.09 & -0.13 & 0.09 & 0.01 & 0.02 & -0.05 & -0.05 & -0.09 & 1 & & & & & & & & \\
\hline MV & 0.03 & 0.06 & 0.32 & -0.37 & -0.01 & -0.02 & 0.07 & 0.54 & 0.10 & -0.24 & 1 & & & & & & & \\
\hline $\mathrm{P} / \mathrm{B}$ & 0.00 & 0.09 & -0.10 & -0.05 & 0.03 & 0.03 & 0.00 & -0.03 & 0.01 & -0.03 & -0.02 & 1 & & & & & & \\
\hline SALES & 0.03 & 0.07 & 0.40 & -0.20 & -0.01 & -0.01 & 0.06 & 0.40 & 0.06 & -0.07 & 0.78 & -0.01 & 1 & & & & & \\
\hline $\mathrm{CASH}$ & 0.03 & 0.06 & 0.25 & -0.16 & -0.07 & -0.05 & 0.04 & 0.37 & 0.05 & -0.07 & 0.67 & -0.02 & 0.69 & 1 & & & & \\
\hline PPE & 0.03 & 0.06 & 0.43 & -0.13 & 0.08 & 0.01 & 0.05 & 0.34 & 0.06 & -0.10 & 0.69 & -0.01 & 0.82 & 0.53 & 1 & & & \\
\hline SG\&A & 0.04 & 0.08 & 0.35 & -0.22 & 0.01 & 0.02 & 0.04 & 0.46 & 0.06 & -0.09 & 0.79 & 0.00 & 0.86 & 0.68 & 0.70 & 1 & & \\
\hline $\mathrm{D} / \mathrm{E}$ & 0.00 & 0.00 & 0.01 & -0.06 & -0.01 & -0.01 & 0.00 & 0.00 & 0.00 & 0.01 & 0.01 & 0.20 & 0.02 & 0.02 & 0.01 & 0.01 & 1 & \\
\hline ROE & 0.00 & 0.00 & -0.12 & -0.19 & 0.01 & 0.01 & 0.00 & 0.00 & 0.01 & -0.01 & 0.01 & 0.00 & -0.02 & -0.02 & -0.05 & -0.02 & -0.07 & 1 \\
\hline
\end{tabular}


Table 4. Regression analysis 'Sample' Regression analysis of the LuxLeaks Dummy 'Sample' as the dependent variable and the transparency measures as the independent variables. (Standard errors are presented in parentheses; $*$, ** and *** denote significance at the $10 \%, 5 \%$ and $1 \%$ levels, respectively.)

\begin{tabular}{|c|c|c|c|c|c|c|}
\hline & (1) & (2) & (3) & (4) & (5) & (6) \\
\hline & $\begin{array}{l}\text { Coef. (Std. } \\
\text { Err.) }\end{array}$ & $\begin{array}{l}\text { Coef. (Std. } \\
\text { Err.) }\end{array}$ & $\begin{array}{l}\text { Coef. (Std. } \\
\text { Err.) }\end{array}$ & $\begin{array}{l}\text { Coef. (Std. } \\
\text { Err.) }\end{array}$ & $\begin{array}{l}\text { Coef. (Std. } \\
\text { Err.) }\end{array}$ & $\begin{array}{l}\text { Coef. (Std. } \\
\text { Err.) }\end{array}$ \\
\hline $\begin{array}{l}\text { Dependent } \\
\text { variable: }\end{array}$ & Sample & Sample & Sample & Sample & Sample & Sample \\
\hline VarNetInco & $\begin{array}{l}205.73 * * * \\
(20.98)\end{array}$ & & & & & \\
\hline ResVarNetI & $\begin{array}{l}205.21 * * * \\
(22.36)\end{array}$ & & & & & \\
\hline CorrCFoAcc & & $\begin{array}{l}-2.40 * * * \\
(0.10)\end{array}$ & & & & \\
\hline ResCorrCF & & $\begin{array}{l}2.42 * * * \\
(0.10)\end{array}$ & & & & \\
\hline ResRawAcc & & & $\begin{array}{l}0.01 \\
(0.01)\end{array}$ & & & \\
\hline AnalCov & & & & $\begin{array}{l}-0.00 * * * \\
(0.00)\end{array}$ & & \\
\hline AuditD & & & & & $\begin{array}{l}-0.04 * * \\
(0.02)\end{array}$ & \\
\hline IFRSChaD & & & & & & $\begin{array}{l}-0.10 * * * \\
(0.02)\end{array}$ \\
\hline $\mathrm{P} / \mathrm{B}$ & $\begin{array}{l}0.00 \\
(0.00)\end{array}$ & $\begin{array}{l}0.00 \\
(0.00)\end{array}$ & $\begin{array}{l}-0.00 \\
(0.00)\end{array}$ & $\begin{array}{l}-0.00 \\
(0.00)\end{array}$ & $\begin{array}{l}-0.00 \\
(0.00)\end{array}$ & $\begin{array}{l}-0.00 \\
(0.00)\end{array}$ \\
\hline SALES & $\begin{array}{l}0.01 * * \\
(0.01)\end{array}$ & $\begin{array}{l}-0.03 * * * \\
(0.01)\end{array}$ & $\begin{array}{l}0.03^{* * * *} \\
(0.00)\end{array}$ & $\begin{array}{l}0.02 * * * \\
(0.00)\end{array}$ & $\begin{array}{l}0.03^{* * *} \\
(0.00)\end{array}$ & $\begin{array}{l}0.02 * * * \\
(0.00)\end{array}$ \\
\hline CASH & $\begin{array}{l}0.00 \\
(0.00)\end{array}$ & $\begin{array}{l}-0.01 * * * \\
(0.00)\end{array}$ & $\begin{array}{l}0.01^{* * * *} \\
(0.00)\end{array}$ & $\begin{array}{l}0.01 * * * \\
(0.00)\end{array}$ & $\begin{array}{l}0.01 * * * \\
(0.00)\end{array}$ & $\begin{array}{l}0.01 * * * \\
(0.00)\end{array}$ \\
\hline PPE & $\begin{array}{l}-0.01 * * * \\
(0.00)\end{array}$ & $\begin{array}{l}0.07 * * * \\
(0.00)\end{array}$ & $\begin{array}{l}-0.02 * * * \\
(0.00)\end{array}$ & $\begin{array}{l}-0.02 * * * \\
(0.00)\end{array}$ & $\begin{array}{l}-0.02 * * * \\
(0.00)\end{array}$ & $\begin{array}{l}-0.02 * * * \\
(0.00)\end{array}$ \\
\hline SG\&A & $\begin{array}{l}0.02^{* * * *} \\
(0.00)\end{array}$ & $\begin{array}{l}0.00 \\
(0.00)\end{array}$ & $\begin{array}{l}0.02^{* * * *} \\
(0.00)\end{array}$ & $\begin{array}{l}0.02^{* * * *} \\
(0.00)\end{array}$ & $\begin{array}{l}0.03^{* * * *} \\
(0.00)\end{array}$ & $\begin{array}{l}0.03^{* * * *} \\
(0.00)\end{array}$ \\
\hline MV & $\begin{array}{l}-0.00 \\
(0.00)\end{array}$ & $\begin{array}{l}-0.02 * * * \\
(0.00)\end{array}$ & $\begin{array}{l}-0.02 * * * \\
(0.00)\end{array}$ & $\begin{array}{l}-0.01 * * * \\
(0.00)\end{array}$ & $\begin{array}{l}-0.04 * * * \\
(0.00)\end{array}$ & $\begin{array}{l}-0.04 * * * \\
(0.00)\end{array}$ \\
\hline $\mathrm{D} / \mathrm{E}$ & $\begin{array}{l}0.00 \\
(0.00)\end{array}$ & $\begin{array}{l}0.00 \\
(0.00)\end{array}$ & $\begin{array}{l}0.00 \\
(0.00)\end{array}$ & $\begin{array}{l}0.00 \\
(0.00)\end{array}$ & $\begin{array}{l}0.00 \\
(0.00)\end{array}$ & $\begin{array}{l}0.00 \\
(0.00)\end{array}$ \\
\hline ROE & $\begin{array}{l}0.00 * * \\
(0.00)\end{array}$ & $\begin{array}{l}0.00 * * * \\
(0.00)\end{array}$ & $\begin{array}{l}-0.00 \\
(0.00)\end{array}$ & $\begin{array}{l}-0.00 \\
(0.00)\end{array}$ & $\begin{array}{l}-0.00 \\
(0.00)\end{array}$ & $\begin{array}{l}-0.00 \\
(0.00)\end{array}$ \\
\hline No. of Obs. & 6073.00 & 6071.00 & 9858.00 & 10089.00 & 10314.00 & 10314.00 \\
\hline R-Squared & 0.22 & 0.29 & 0.17 & 0.17 & 0.19 & 0.19 \\
\hline
\end{tabular}


Table 5. Regression analysis of the LuxLeaks Dummy 'Sample' and 'SampleRuling" as the dependent variable and the transparency measures as the independent variables. (Standard errors are presented in parentheses; $* * *$ and $* * *$ denote significance at the $10 \%, 5 \%$ and $1 \%$ levels, respectively.)

\begin{tabular}{|c|c|c|}
\hline & (1) & (2) \\
\hline & Coef. (Std. Err.) & Coef. (Std. Err.) \\
\hline Dependent variable & Sample & SampleRuling \\
\hline \multirow{2}{*}{ VarNetInco } & $-22,644.96 * * *$ & $-1,146.85$ \\
\hline & $(3,449.94)$ & $(1,009.08)$ \\
\hline \multirow[t]{2}{*}{ ResVarNetI } & 29.75 & 4.04 \\
\hline & $(25.71)$ & (7.52) \\
\hline \multirow[t]{2}{*}{ CorrCFoAcc } & $-2.33 * * *$ & $-0.10 * * *$ \\
\hline & $(0.11)$ & $(0.03)$ \\
\hline \multirow[t]{2}{*}{ ResCorrCF } & $2.34 * * *$ & $0.10^{* * *}$ \\
\hline & $(0.11)$ & $(0.03)$ \\
\hline \multirow[t]{2}{*}{ ResRawAcc } & 0.01 & 0.00 \\
\hline & $(0.01)$ & $(0.00)$ \\
\hline \multirow[t]{2}{*}{ AnalCov } & $-0.00 * * *$ & $-0.00 *$ \\
\hline & $(0.00)$ & $(0.00)$ \\
\hline \multirow{2}{*}{ AuditD } & -0.01 & 0.00 \\
\hline & $(0.02)$ & $(0.01)$ \\
\hline \multirow[t]{2}{*}{ IFRSChaD } & $-0.05^{* *}$ & -0.00 \\
\hline & $(0.02)$ & $(0.01)$ \\
\hline \multirow[t]{2}{*}{$\mathrm{P} / \mathrm{B}$} & -0.00 & $-0.00 * *$ \\
\hline & $(0.00)$ & $(0.00)$ \\
\hline \multirow[t]{2}{*}{ SALES } & $-0.03 * * *$ & -0.00 \\
\hline & $(0.01)$ & $(0.00)$ \\
\hline \multirow[t]{2}{*}{ CASH } & $-0.01 * * *$ & -0.00 \\
\hline & $(0.00)$ & $(0.00)$ \\
\hline \multirow[t]{2}{*}{ PPE } & $0.06^{* * *}$ & $0.00 * *$ \\
\hline & $(0.00)$ & $(0.00)$ \\
\hline \multirow[t]{2}{*}{ SG\&A } & 0.00 & 0.00 \\
\hline & $(0.00)$ & $(0.00)$ \\
\hline \multirow[t]{2}{*}{ MV } & 0.00 & $0.00 * *$ \\
\hline & $(0.01)$ & $(0.00)$ \\
\hline \multirow[t]{2}{*}{$\mathrm{D} / \mathrm{E}$} & 0.00 & 0.00 \\
\hline & $(0.00)$ & $(0.00)$ \\
\hline \multirow[t]{2}{*}{ ROE } & $0.00 * *$ & 0.00 \\
\hline & $(0.00)$ & $(0.00)$ \\
\hline No. of Obs. & 5840.00 & 5840.00 \\
\hline R-Squared & 0.27 & 0.05 \\
\hline Fixed effects & Year, Country, Industry & Year, Country, Industry \\
\hline
\end{tabular}


Table 6. Regression analysis of the LuxLeaks Dummy 'SampleRuling' as the dependent variable and the transparency measures as the independent variables. (Standard errors are presented in parentheses; $*$, ** and $* * *$ denote significance at the $10 \%, 5 \%$ and $1 \%$ levels, respectively)
(1)
(2)
(3)
(4)
(5)
(6)

Coef. (Std. Coef. (Std. Coef. (Std. Coef. (Std. Coef. (Std. Coef. (Std. Err.)

Err.)

Err.)

Err.)

Err.)

Err.)

$\begin{array}{ll}\begin{array}{l}\text { Dependent } \\ \text { variable }\end{array} & \text { Sample } \\ \text { VarNetInco } & 10.03^{*} \\ & (5.83) \\ \text { ResVarNetI } & 11.19^{*} \\ & (6.21)\end{array}$

CorrCFoAcc

$-0.10 * * *$
$(0.03)$
$0.10 * * *$
$(0.03)$

ResCorrCF

ResRawAcc

$-0.00$

$(0.00)$

AnalCov

$\begin{array}{ll}(0.00) & -0.00 * \\ & (0.00)\end{array}$

AuditD

IFRSChaD

0.00

(0.01)

P/B

$-0.00 * *$

$(0.00)$

$-0.00 * *$

$(0.00)$

SALES

$-0.00$

$-0.00$

$(0.00)$

(0.00)

CASH

$-0.00$

$-0.00$

(0.00)

PPE

$-0.00$

0.00 **

(0.00)

$(0.00)$

$-0.00$

(0.00)

$(0.00)$

MV

0.00 **

0.00

(0.00)

(0.00)

D/E

0.00

0.00

$(0.00)$

ROE

$(0.00)$

0.00

0.00

(0.00)

(0.00)

No. of Obs. $\quad 6,073.00$

$6,071.00$

0.05

Year,

Year,

Country,

$-0.00^{*}$

$(0.00)$

0.00

$(0.00)$

0.00

$(0.00)$

$-0.00$

$(0.00)$

0.00

$(0.00)$

$-0.00$

$(0.00)$

0.00

$(0.00)$

$-0.00$

$-0.00^{*}$

$-0.01$

$(0.00)$

R-Squared

Country,

Industry

$(0.00)$

$-0.00 *$

$(0.00)$

$-0.00 *$

$(0.00)$
0.00

0.00

$(0.00)$

(0.00)

$(0.00)$

0.00

0.00

(0.00)

0.00

$(0.00)$

Fixed effects

Industry

$9,858.00$
0.04
Year,
Country,
Industry

$-0.00$

(0.00)

0.00

$(0.00)$

$(0.00)$

$(0.00)$

$0.00 * *$

(0.00)

0.00

$(0.00)$

0.00

(0.00)

(0.00)

$-0.00$

$-0.00$

$-0.00$

(0.00)

(0.00)

(0.00)

0.00

(0.00)

0.00

0.00

(0.00)

(0.00)

$-0.00$

$-0.00$

$-0.00$

(0.00)

(0.00)

(0.00)

$10,089.00$
0.04
Year,
Country,
Industry

$10,314.00$

0.05

$10,314.00$

Year,

Country,

0.05

Year,

Industry

Country,

Industry 